\title{
Evaluation Study: Functions of Management of Sports Facilities During the COVID-19 Pandemic
}

\author{
Ahmad Nasrulloh ${ }^{1, *}$ Sumaryanto Sumaryanto ${ }^{1}$ Sumarjo Sumarjo ${ }^{1}$ Sigit Nugroho ${ }^{1}$ \\ ${ }^{I}$ Department of Sport Science Yogyakarta State University, Yogyakarta, Indonesia \\ *Corresponding author.Email: ahmadnasrulloh@uny.ac.id
}

\begin{abstract}
This study aims to conduct comprehensive research on the evaluation of the management function of sports facilities during the COVID-19 pandemic. This research is an evaluation type with a descriptive-evaluative method approach. This research was conducted with the CIPP evaluation model (Context, Input, Process, and Product). The data sources of this research consisted of stakeholders, leaders, and managers of sports facilities unit managers at the Faculty of Sports Science, Yogyakarta State University. Data collection was obtained from the results of observations and interviews with data sources to evaluate the management function of sports facilities. Data analysis is divided into three flows that occur simultaneously including data reduction, data presentation, and concluding. The results of the study found that the implementation of the management function was constrained by limited personnel, as well as restrictions on service hours. These difficulties include difficulties in distributing staff work schedules, difficulties in completing work that cannot be done online, delays in delivering information, difficulties in education about health protocols, and difficulties related to funding. The steps taken are by organizing staff on jobs that are following their skills, making work schedules, and maintaining good service to users, and carrying out facility management following health protocols and government regulations. The interest of users of sports facilities during the COVID-19 pandemic has decreased, which has an impact on income. Recommendation on the matter is the use of sports facilities and infrastructure effectively and efficiently, evaluating programs, preparing programs and strategies that can attract clients, then promoting and publishing, as well as creating an Android-based integrated service system so that it is expected to increase revenue.
\end{abstract}

Keywords: Evaluation, Management Functions, Sports Facilities, Pandemic, COVID-19

\section{INTRODUCTION}

Coronavirus disease (COVID-19) is a respiratory tract infection caused by severe acute respiratory syndrome coronavirus 2 (SARS-CoV-2). It is well known that COVID-19 is a very serious world health problem. This COVID-19 case originated from information from the Old Health Organization (WHO) on December 31, 2019, which stated that there was a cluster case of pneumonia with unclear etiology in Wuhan City, Hubei Province, China. Public Health Emergency of International Concern (PHEIC).

Cases of COVID 19 quickly spread throughout the world, so that in March 2020, WHO declared COVID19 a global pandemic. The first case in Indonesia was announced by the President of the Republic of Indonesia on March 2, 2020, namely, there have been 2 confirmed cases of COVID-19. In Indonesia. Since then, the Indonesian government has begun to take preventive measures to prevent the wider spread. To date, Indonesia has reported through BNPB the number of COVID-19 cases in Indonesia has reached more than 1 million positive cases of COVID-19. The data shows that the transmission of COVID 19 is still showing a significant increase, this can be seen from the increasing number of positive cases. The low spread of COVID-19 cases in Indonesia has had a significant effect on the economy.

The Faculty of Sports Science has services in the field of managing sports facilities to support the tri dharma of higher education. The development of sports facilities services is part of the development of the sports industry,(Nasrulloh et al., 2019). Various sports facilities services available at the Faculty of Sports Science, Yogyakarta State University are sports buildings, swimming pools, tennis courts, basketball courts, fitness centers as well as athletic stadiums and soccer fields. However, sports facility management services at the Yogyakarta State University's Faculty of Sports Science were also directly affected by the 
negative impact of covid 19. This can be shown from the total value of income or income during the pandemic, which has decreased significantly.

The decline in income from various sports facility services at the Faculty of Sports Science, Yogyakarta State University cannot be tolerated. Therefore, it is very necessary to evaluate the management function of sports facilities during the COVID-19 pandemic. Evaluation is an applied science of social research that uses a set of skills and tools to carry out an intervention in determining success (Nkwake, 2015). Patton (2018) says that basically evaluation is about assessing achievement, value, and significance. The assessment is by the act of persuasion aimed at a particular audience regarding the solution to the problem. Evaluation is a cutting-edge concept that includes the phases of selecting information, obtaining, analyzing, transferring, use and making decisions about curriculum quality (Hakan \& Seval, 2011). Evaluation is applied to gather information on the achievement or quality of programs, products, people, policies, proposals, or plans. Operationally, evaluation is the process of describing, obtaining, reporting, and applying descriptive information and justifying the value of objects, as defined by criteria such as quality, value, honesty, fairness, feasibility, cost, efficiency, safety, and significance (Stufflebeam \& Coryn, 2014).

Functionally, evaluation is the process of describing, obtaining, recording, and applying descriptive and judgmental information to decide the value, usefulness, importance, and accuracy of a particular object, promote transparency, disseminate effective practice, and clarify complex phenomena (Duman \& Akbas, 2017). ). In the end, the purpose of an evaluation is to determine the fulfillment of goals and objectives, efficiency, effectiveness, impact, and sustainability of a program (Hunter \& Nielsen, 2013). Another opinion says that evaluation aims to determine the value of a program, policy or project, to improve performance, results, or policies that are being implemented (Arthur \& Cox, 2014). Widoyoko (2017) said that the purpose of the evaluation is to obtain accurate and objective information about a program.

The need to evaluate the management function of sports facilities within the Faculty of Sports Science, Yogyakarta State University is to find and determine new policy directions in carrying out sports facilities management functions during the COVID-19 pandemic. The management function is the main task or main task that must be carried out by the leadership in any organization. A good management organization process must meet management function standards including planning, organizing, leading, and control, (Nasrulloh et al., 2020). The management function itself consists of four functions, namely planning, organizing, leading, and control (Eksteen, 2014). Suherman, (2002) says that the management function is the process of planning, organizing, directing, and controlling the efforts of members, organizations, the use, and control of human resources owned by the organization. Implementation management function has a positive impact on service quality (Nasrulloh et al., 2021). So that to improve service quality, it is necessary to evaluate management functions related to planning, organizing, directing, and controlling the efforts of staff, use, and control of human resources owned by the management of sports facilities during the COVID-19 pandemic.

\section{METHOD}

This research is a type of program evaluation with a descriptive-evaluative method approach. Program evaluation attempts to identify the sources of variation in program outcomes both from within and outside the program while determining whether the sources of variation or even the outcomes themselves are desirable or undesirable (Frye \& Hemmer, 2012: 289). The descriptive method explains that this research was conducted to describe everything about the evaluation of the management function of sports facilities at the Faculty of Sports Science, Yogyakarta State University during the COVID-19 pandemic related to the concept of preparation, implementation, and the impact or results from its causes.

The research approach used is qualitative. The background that can be used as a logical argument for the selection of this approach is: (1) the instrument used for data collection is in the form of focused and in-depth interview sheets, therefore the researcher himself is a human instrument, (2) the data collected is in the form of a set of documents and verbal information. from the answers of the respondents and (3) so that the truth of the information from the interview results can be accounted for, it requires data triangulation.

The evaluation model that was selected and considered representative of the problems studied was the context, input, process, and product (CIPP) model. The first three elements of the CIPP model are useful for evaluation studies focused on improvement (formative), while the Product approach, the fourth element, is particularly appropriate for summative (final) studies (Frye \& Hemmer, 2012: 296). The CIPP evaluation model is designed to systematically guide both evaluators and stakeholders in asking relevant questions and conducting assessments at the beginning of the project (context and input evaluation), while in progress (input and process evaluation), and at the end (product evaluation) ( Zhang et al., 2011: 59). (Guyadeen \& Seasons, 2016). The implementation of the CIPP model can touch various fields, such as Education projects, government policies, human resources (HR) training programs, and so on. The rationale that can be put forward is why this model was chosen because the CIPP model 
allows researchers to be able to carry out comprehensive evaluation activities of the management function of sports facilities at the Faculty of Sports Science, Yogyakarta State University.

\section{RESULTS AND DISCUSSION}

\subsection{Results}

\subsubsection{Context evaluation}

Context evaluation is used to find out whether the program is following the right objectives and also to assess the results in response to needs, problems, and intended goals. Interviews were conducted on stakeholders and management staff of sports facilities at the Faculty of Sports Science, Yogyakarta State University. The results of the interviews in terms of context are as follows.

\subsubsection{Facility Management}

The results of interviews about the management of facilities management to the resource persons can be seen in the following table:

Table 1. Interview Results of Respondents Aspect Context About Facility Management

\begin{tabular}{|c|c|c|}
\hline No & Source person & Interview result \\
\hline 1. & Respondent 1 & $\begin{array}{l}\text { "Adjustment of schedule distribution and workload distribution to be effective and efficient in } \\
\text { completing work in the GOR environment" }\end{array}$ \\
\hline 2. & Respondent 2 & $\begin{array}{l}\text { "We were asked by the leadership (Dean/Rector) to prepare supporting facilities for the Covid-19 } \\
\text { pandemic, including: } \\
\text { a) Prepare sinks, liquid soap, tissue, trash cans, and others in several places on campus, } \\
\text { b) Procurement of equipment for spraying and fumigating disinfectants, thermo guns, oxy meters, } \\
\text { self-isolation } \\
\text { c) patient waste plastic (yellow plastic), procurement of vitamins for leaders and staff, } \\
\text { d) Arrangement of seating/waiting chairs. } \\
\text { e) WFO/WFH Scheduling for staff in UKBMN, } \\
\text { f) Preparation of Student Rest House, and others" }\end{array}$ \\
\hline 3. & Respondent 3 & $\begin{array}{l}\text { "Management follows the rules from the center in this case from the university, always follows the } \\
\text { rules and health protocols from both the center and the province" }\end{array}$ \\
\hline 4. & Respondent 4 & "Management with covid management and protocol" \\
\hline 5. & Respondent 5 & $\begin{array}{l}\text { "We adjust the personnel/workforce. For example, if there is an indication of OTG, it can be replaced } \\
\text { by something else." }\end{array}$ \\
\hline 6. & Respondent 6 & $\begin{array}{l}\text { "All management must participate in maintaining and be responsible for improving the quality of } \\
\text { service" }\end{array}$ \\
\hline 7. & Respondent 7 & $\begin{array}{l}\text { "The management of HSC fitness management is under government recommendations and } \\
\text { implementing health protocols" }\end{array}$ \\
\hline 8. & Respondent 8 & "Adjusting the circular from the leadership" \\
\hline 9. & Respondent 9 & "Walking as usual" \\
\hline 10. & Respondent 10 & $\begin{array}{l}\text { "Management of facility management during the pandemic, with equipment maintenance, } \\
\text { implementing the COVID } 19 \text { health protocol rules, limiting the number of visitors, wearing masks, } \\
\text { sterilizing fitness equipment" }\end{array}$ \\
\hline
\end{tabular}

Source: Results of interviewees, 2021

Based on the results of interviews regarding the management of facilities management, it can be concluded that the majority of respondents stated that the management of sports facilities was carried out by health protocols issued by the center, province, and Yogyakarta State University.

\subsubsection{Application of Management Function}

The results of interviews about the application of management functions to resource persons can be seen in the following table: 
Table 2. Interview Results of Respondents Aspect Context About the Implementation of Management Functions

\begin{tabular}{|c|l|l|}
\hline No. & Source person & \multicolumn{1}{c|}{ Interview Result } \\
\hline 1. & Respondent 1 & $\begin{array}{l}\text { "Can be implemented well, although in time the process must be sequential and gradual due to } \\
\text { limited manpower" }\end{array}$ \\
\hline 2. & Respondent 2 & $\begin{array}{l}\text { "Services are attempted to be carried out properly, the function of office service management to } \\
\text { stakeholders/customers (lecturers, educators, students) is affected due to the limitation of service } \\
\text { hours (WFH/WFO), optimized online/online services. Also prepared are the contacts for each officer } \\
\text { who can be easily contacted at any time to come to the office." }\end{array}$ \\
\hline 3. & Respondent 3 & $\begin{array}{l}\text { "It can be implemented well, meaning that the users of the GOR facilities follow and obey the } \\
\text { existing regulations properly following the agreement of both parties" }\end{array}$ \\
\hline 4. & Respondent 4 & $\begin{array}{l}\text { "It is very limited and not optimal, it takes a lot of personnel or personnel and a lot of operations, but } \\
\text { this covid condition makes the number of employees who enter is limited so that it is less than } \\
\text { optimal in service" }\end{array}$ \\
\hline 5. & Respondent 5 & "Running smoothly" \\
\hline 6. & Respondent 6 & "Can" \\
\hline 7. & Respondent 7 & "Yes, it can be implemented well but there are some small obstacles but they can be handled well" \\
\hline 8. & Respondent 8 & "Yes, because the controlling aspect is prioritized" \\
\hline 9. & Respondent 9 & "It can run well because the Covid-19 pandemic only requires habit adjustments" \\
\hline 10. & Respondent 10 & $\begin{array}{l}\text { "The implementation of the management function can be done well, although a thorough evaluation } \\
\text { needs to be done" }\end{array}$ \\
\hline
\end{tabular}

Source: Results of interviewees, 2021

Based on the results of the interview, it is known that almost all respondents stated that the implementation of management functions can be carried out well, although it is carried out in a limited manner and with various adjustments to the Covid situation. The implementation of management functions is constrained by limited personnel, as well as restrictions on service hours.

\subsubsection{Purpose of Application of Management Function}

The results of interviews about the purpose of implementing the management function on the resource persons can be seen in Table below:

Table 3. Interview Results of Respondents Aspects of Context About the Purpose of Implementation of Management Functions

\begin{tabular}{|c|c|c|}
\hline No & Source person & Interview result \\
\hline 1. & Respondent 1 & $\begin{array}{l}\text { "Adjusting with leadership policies and dividing workloads as effectively and efficiently as possible } \\
\text { by optimizing existing human resources" }\end{array}$ \\
\hline 2. & Respondent 2 & $\begin{array}{l}\text { "So that services to all stakeholders are not disrupted, but with a more regulated case health protocol, } \\
\text { so that all are healthy, safe, and the targets/achievements of management can be met/achieved" }\end{array}$ \\
\hline 3. & Respondent 3 & $\begin{array}{l}\text { "Maintaining that service functions and cooperation continue to run well and can maintain a } \\
\text { consistent prevention of the spread of COVID-19" }\end{array}$ \\
\hline 4. & Respondent 4 & "So that employees can still work and can stay BEP" \\
\hline 5. & Respondent 5 & "So that the pool water regulation can be as clear as possible because that's what we sell to the public" \\
\hline 6. & Respondent 6 & $\begin{array}{l}\text { "Doing directives that can determine what work must be done, such as what priorities employees } \\
\text { must do" }\end{array}$ \\
\hline 7. & Respondent 7 & $\begin{array}{l}\text { "The function of management is to meet standards under government regulations and also health } \\
\text { protocols during the COVID-19 pandemic" }\end{array}$ \\
\hline 8. & Respondent 8 & "So that services to members can continue to be carried out" \\
\hline 9. & Respondent 9 & "Maintenance function and implementation of the process for users" \\
\hline 10. & Respondent 10 & $\begin{array}{l}\text { "The management function during the pandemic is more emphasized on how to provide more safety } \\
\text { services to create a sense of security, comfort, and health for both employees and members. } \\
\text { Output the income has also increased }\end{array}$ \\
\hline
\end{tabular}

Source: Results of interviewees, 2021

Based on the results of the interviews, it can be seen that most of the respondents stated that the purpose of implementing the management function is to service functions and cooperation with stakeholders continue to run well. In addition, it aims to keep the management function during the pandemic period running and continue to provide security guarantees to employees and members.

\subsubsection{Facility Management Planning}

The results of interviews about the planning of facilities management to the resource persons can be seen in the following table: 
Table 4. Interview Results of Respondents Aspect Context About Facility Management Planning

\begin{tabular}{|c|l|l|}
\hline No & Source person & \\
\hline 1. & Respondent 1 & "The plan is more about maintaining and maintaining the existing facilities in the GOR environment" \\
\hline 2. & Respondent 2 & $\begin{array}{l}\text { "Planning in the field of procurement of supporting needs for the Covid-19 health protocol is indeed } \\
\text { prioritized, by looking at the condition of the urgent need for tools, drugs, materials to be fulfilled" }\end{array}$ \\
\hline 3. & Respondent 3 & $\begin{array}{l}\text { "Keep communicating and collaborating with users both from within and from outside FIK UNY, and } \\
\text { policies always adjust to pandemic conditions with the approval of the superiors" }\end{array}$ \\
\hline 4. & Respondent 4 & "There is always planning and evaluation every month with the team" \\
\hline 5. & Respondent 5 & $\begin{array}{l}\text { "Scheduling of personnel is fixed, only operating hours are limited to two shifts. 06.00 - 11.00 and } \\
\text { afternoon 14.00 - 17.00" }\end{array}$ \\
\hline 6. & Respondent 6 & $\begin{array}{l}\text { "Creating a business strategy so that we can achieve our goals as efficiently and effectively as } \\
\text { possible and to increase the productivity of the businesses we manage" }\end{array}$ \\
\hline 7. & Respondent 7 & $\begin{array}{l}\text { "We hold limited meetings for managers and employees and also invite leaders and parties who are } \\
\text { competent in the field of handling covid 19 (doctors) so that a facility management plan will be } \\
\text { created following health protocols and government regulations during the COVID-19 pandemic and } \\
\text { we will carry out this plan." }\end{array}$ \\
\hline 8. & Respondent 8 & "Create a clear timeline with targets" \\
\hline 9. & Respondent 9 & "Implementing additional facilities for process implementation" \\
\hline 10. & Respondent 10 & "Planning in terms of readiness of fitness facilities, human resources and services" \\
\hline
\end{tabular}

Source: Results of interviewees, 2021

Based on the results of the interviews, it can be seen that most of the respondents stated that the facility management planning was still being implemented. The plan is formulated policies that adapt to pandemic conditions with the approval of superiors. Facility management planning is adjusted to health protocols and government regulations during the COVID-19 pandemic.

\subsubsection{Facility Management Long Term Plan}

The results of interviews about the long-term plan of facility management to the resource persons can be seen in the following table: 
Table 5. Interview Results of Respondents Aspect Context About Long-Term Facility Management Plan

\begin{tabular}{|c|c|c|}
\hline No & Source person & Interview result \\
\hline 1. & Respondent 1 & $\begin{array}{l}\text { "Our plan after the pandemic is to prepare and condition if the GOR will be used normally as before } \\
\text { the pandemic" }\end{array}$ \\
\hline 2. & Respondent 2 & $\begin{array}{l}\text { "Management of sports facilities remains a priority to be maintained continuously, sustainably, } \\
\text { including adding sports facilities, including: } \\
\text { a) Making } 2 \text { tribunes on the sand volleyball court } \\
\text { b) Takraw soccer field } \\
\text { c) Construction of wells for irrigation in grapnel and sand volleyball courts } \\
\text { d) Also the addition of a water pump for watering plants in the GPLA yard. } \\
\text { Because we believe the Covid-19 pandemic will end, Insha Allah, who knows when it will end?" }\end{array}$ \\
\hline 3. & Respondent 3 & $\begin{array}{l}\text { "Always follow the changes and developments of the times so that we can still provide the best service } \\
\text { for users of GOR facilities, for example, the arrangement of meeting rooms, changing rooms, toilets, } \\
\text { cleanliness, parking lots, collaborating with agencies or clubs, lighting, management services, security } \\
\text { and so on." }\end{array}$ \\
\hline 4. & Respondent 4 & "After the pandemic can be further developed more optimally" \\
\hline 5. & Respondent 5 & $\begin{array}{l}\text { "In theory, the pool will not have a problem with viruses, because, with water management, medicine } \\
\text { is always given after every operation. Making water acidic can kill viruses. We need to socialize } \\
\text { through videos so that people are not afraid to go to the pool, as a result, more tickets are sold." }\end{array}$ \\
\hline 6. & Respondent 6 & $\begin{array}{l}\text { "Creating effective and productive governance through increasing operating revenues and conducting } \\
\text { strategic analysis that can find the company's dynamic advantages to be optimized in response to } \\
\text { increasingly competitive competition" }\end{array}$ \\
\hline 7. & Respondent 7 & $\begin{array}{l}\text { "In my opinion, we will continue to implement the facility management that we have implemented } \\
\text { according to the health protocols and government regulations regarding the COVID-19 pandemic } \\
\text { because it is very good for all of us and we will evaluate it every month, it's just that maybe the } \\
\text { regulations are a bit loose compared to the time of the COVID-19 pandemic" }\end{array}$ \\
\hline 8. & Respondent 8 & "Developing programs that are efficient for users of tennis court facilities" \\
\hline 9. & Respondent 9 & $\begin{array}{l}\text { "Maintenance of facility functions that have exceeded their economic life and get used to the new } \\
\text { normal post-pandemic" }\end{array}$ \\
\hline 10. & Respondent 10 & $\begin{array}{l}\text { "The long-term plan after the COVID-19 pandemic is to immediately draw up a strategic plan about } \\
\text { what must be done to improve facilities and improve services. With a new order after the pandemic } \\
\text { period is over" }\end{array}$ \\
\hline
\end{tabular}

\section{Source: Results of interviewees, 2021}

Based on the results of the interviews, it can be seen that most of the respondents stated that they still made long-term plans for the management of sports facilities. Apart from keeping existing sports facilities to be maintained/maintained continuously, a plan period the long term was made to develop programs that were efficient by adjusting the new order after the COVID-19 pandemic.

\subsubsection{Input evaluation}

An evaluation of the input aspects of the sports facility management function is carried out to assess procedural plans, staffing requirements, and budgets for their feasibility and potential cost-effectiveness in terms of meeting targeted needs and achieving objectives. The results of the interviews in terms of input are as follows.

\subsubsection{Implementation of Organizing Functions During a Pandemic}

The results of interviews regarding the implementation of the organizing function during the pandemic to informants can be seen in the following table: 
Table 6. Interview Results of Respondents Input Aspect About the Implementation of Organizing Functions During a Pandemic

\begin{tabular}{|c|c|c|}
\hline No & Source person & Interview result \\
\hline 1. & Respondent 1 & $\begin{array}{l}\text { "The function performed is to do work by optimizing existing human resources without reducing the } \\
\text { results/achievements to be achieved" }\end{array}$ \\
\hline 2. & Respondent 2 & $\begin{array}{l}\text { "The organizing function for the maintenance work of sports facilities is endeavored to be carried out } \\
\text { by making work schedules/pickets for friends in the Sub. UKBMN Coordinate" }\end{array}$ \\
\hline 3. & Respondent 3 & $\begin{array}{l}\text { "Implementing policies by the conditions of the COVID-19 pandemic, regulating officer pickets, one- } \\
\text { door service, maintaining procedures, maintaining good service with users" }\end{array}$ \\
\hline 4. & Respondent 4 & "Keep going well" \\
\hline 5. & Respondent 5 & $\begin{array}{l}\text { "We have assigned certain tasks to employees according to their physical abilities and skills, and } \\
\text { maintain their privacy" }\end{array}$ \\
\hline 6. & Respondent 6 & "Developing the organization and working groups as well as the division of work responsibilities" \\
\hline 7. & Respondent 7 & $\begin{array}{l}\text { "Implementation of the organizing function in facility management applies health protocols and is } \\
\text { following government regulations" }\end{array}$ \\
\hline 8. & Respondent 8 & "Controlling and auditing is applied according to the specified time" \\
\hline 9. & Respondent 9 & "Functions normally" \\
\hline 10. & Respondent 10 & $\begin{array}{l}\text { "The organizing function is carried out to organize all personnel according to their respective job } \\
\text { descriptions so that they are more focused on the goals to be achieved" }\end{array}$ \\
\hline
\end{tabular}

Source: Results of interviewees, 2021

Based on the results of interviews, it is known that most of the respondents stated that the organizing function was still carried out during the pandemic by adjusting the conditions of the COVID-19 pandemic. The steps taken are by organizing human resources in jobs that are under their skills, making work schedules, and maintaining good service to users, and carrying out facility management following health protocols and government regulations.

\subsubsection{Staff Work on Duty}

Results Interview about the staff working according to their duties towards resource persons can be seen in the following table:

Table 7. Interview Results of Respondents Input Aspects About Staff Working According to Tasks

\begin{tabular}{|c|l|l|}
\hline No & Source person & \\
\hline 1. & Respondent 1 & "Work according to the duties and functions" \\
\hline 2. & Respondent 2 & "Yes, God willing. Work according to its function with work scheduling (WFH/WFO)" \\
\hline 3. & Respondent 3 & "Yes, because there has been good direction and cooperation from the parties concerned" \\
\hline 4. & Respondent 4 & "Yes" \\
\hline 5. & Respondent 5 & $\begin{array}{l}\text { "Yes, it is. When someone has a Caesarean section, we change the schedule with another employee, } \\
\text { then change it in the future" }\end{array}$ \\
\hline 6. & Respondent 6 & "Yes" \\
\hline 7. & Respondent 7 & $\begin{array}{l}\text { "Yes, it's just that there are additional tasks such as those we are given the task of (measuring body } \\
\text { temperature) some we are tasked with spraying disinfectants and others, basically there are additional } \\
\text { tasks related to health care during the COVID-19 pandemic" }\end{array}$ \\
\hline 8. & Respondent 8 & "Yes, it is by the task" \\
\hline 9. & Respondent 9 & "Yes" \\
\hline 10. & Respondent 10 & "All staff work according to their respective duties" \\
\hline
\end{tabular}

Source: Results of interviewees, 2021

Based on the results of the interview, it can be seen that all respondents stated that all staff worked according to their duties and functions during the COVID-19 pandemic. In addition to carrying out their duties and functions according to their job responsibilities, staff also had additional tasks related to health protocols during the COVID-19 pandemic such as measuring body temperature, spraying disinfectant, and others.

\subsubsection{Management Efforts to Improve Service Quality}

The results of interviews about management's efforts to improve the quality of service to resource persons can be seen in the following table: 
Table 8. Interview Results of Respondents Input Aspects About Management Improving Service Quality

\begin{tabular}{|c|l|l|}
\hline No & Source person & \multicolumn{1}{c|}{ Interview result } \\
\hline 1. & Respondent 1 & $\begin{array}{l}\text { "Coordinate with leaders and clients who have provided DP for the event by providing a schedule } \\
\text { postponement policy as desired, a maximum of 2021" }\end{array}$ \\
\hline 2. & Respondent 2 & $\begin{array}{l}\text { "With regular/routine maintenance of OR facilities, also responding immediately if there is a request } \\
\text { for repair of OR infrastructure, if there is work that the Team can do on its own, we will do it, but if } \\
\text { the Team is unable to handle the repairs, we immediately look for outside partners to the repair" }\end{array}$ \\
\hline 3. & Respondent 3 & "As much as possible to always provide good service and meet the standards of service needs" \\
\hline 4. & Respondent 4 & "Held regular workshops and coordination" \\
\hline 5. & Respondent 5 & $\begin{array}{l}\text { "All visitors are subject to health procedures, some of which we interview about the advantages and } \\
\text { disadvantages of the pool. We often serve external research well" }\end{array}$ \\
\hline 6. & Respondent 6 & "Provide fast and responsive service, and maintain courtesy" \\
\hline 7. & Respondent 7 & $\begin{array}{l}\text { "How to implement government regulations and implement health protocols during the COVID-19 } \\
\text { pandemic" }\end{array}$ \\
\hline 8. & Respondent 8 & "Maintaining the collaboration and trust of the members that have been well established" \\
\hline 9. & Respondent 9 & "adding additional facilities for the implementation of health protocols" \\
\hline 10. & Respondent 10 & "Efforts to improve services by emphasizing the progress of COVID-19" \\
\hline
\end{tabular}

Source: Results of interviewees, 2021

Based on the results of the interview, it can be seen that most of the respondents stated that they made various efforts to improve the quality of services during the COVID-19 pandemic. Efforts were made to improve the quality of services during the pandemic, including maintaining sports facilities, responding quickly to repairs if there were infrastructure that needed to be repaired, providing services according to the standard of service needs while still emphasizing the COVID-19 process.

\subsubsection{Member Interests During the Pandemic}

The results of interviews about members' interest during the pandemic towards resource persons can be seen in the following table:

Table 9. Interview Results of Respondents Input Aspect About Member Interests During the Pandemic

\begin{tabular}{|c|l|l|}
\hline No & Source person & \multicolumn{1}{c|}{ Interview result } \\
\hline 1. & Respondent 1 & "Downhill" \\
\hline 2. & Respondent 2 & $\begin{array}{l}\text { "For the venue/OR site, there are those that are not too disturbed by the impact of this Covid-19 } \\
\text { Pandemic, for example at Fitness HSC, at Therapy/Massage HSC, at the Tennis Court, at the } \\
\text { Selabora Unit. In-out income in June 2021, I received information that it is still high (indications of } \\
\text { that external users/users are still satisfied with sports activities/facilities" }\end{array}$ \\
\hline 3. & Respondent 3 & $\begin{array}{l}\text { "There is a downward trend due to the COVID-19 pandemic situation and government regulations are } \\
\text { very strict for activities that involve crowds or mass gatherings" }\end{array}$ \\
\hline 4. & Respondent 4 & "High interest but very limited due to pandemic" \\
\hline 5. & Respondent 5 & $\begin{array}{l}\text { "I'm sure there will still be a lot of interest, but because of government regulations, visitors have } \\
\text { decreased considerably, many have called to ask about the pool" }\end{array}$ \\
\hline 6. & Respondent 6 & "Members' interest is reduced because they also obey government rules" \\
\hline 7. & Respondent 7 & "The trend is starting to increase awareness of health has started to increase, especially sports" \\
\hline 8. & Respondent 8 & "Relatively steady despite a slight decline" \\
\hline 9. & Respondent 9 & "Slightly downhill" \\
\hline 10. & Respondent 10 & $\begin{array}{l}\text { "Interest is reduced because sports (fitness) facilities are public places (in } 1 \text { room) that have the } \\
\text { potential to transmit COVID-19 " }\end{array}$ \\
\hline
\end{tabular}

Source: Results of interviewees, 2021

Based on the results of the interview, it can be seen that most of the respondents stated that the interest in members/users of sports facilities during the COVID19 pandemic has decreased. This is because government regulations are very strict for activities that involve crowds or mass gatherings. A small number of respondents expressed a high but limited interest in government regulations.

\subsubsection{Maintenance of Facilities and Infrastructure}

The results of interviews about the maintenance of facilities and infrastructure to the informants can be seen in the following table: 
Table 10. Interview Results of Respondents Input Aspect About Maintenance of Facilities and Infrastructure

\begin{tabular}{|c|l|l|}
\hline No & Source person & \multicolumn{1}{c|}{ Interview result } \\
\hline 1. & Respondent 1 & "Continue to carry out according to their respective duties" \\
\hline 2. & Respondent 2 & $\begin{array}{l}\text { "Maintenance of sports infrastructure is still carried out properly, remains responsive to } \\
\text { complaints/requests for repair of damaged tools, materials, or others" }\end{array}$ \\
\hline 3. & Respondent 3 & $\begin{array}{l}\text { "Performing periodic maintenance, maintaining the cleanliness of facilities and infrastructure, } \\
\text { spraying disinfectants periodically, making an inventory of existing infrastructure that is feasible } \\
\text { and not feasible" }\end{array}$ \\
\hline 4. & Respondent 4 & "Maintenance continues well" \\
\hline 5. & Respondent 5 & $\begin{array}{l}\text { "Pool maintenance is consistent every day because the machines are old. Because the operations } \\
\text { are continuous, we take a strategy to rest some machines, for backup and savings." }\end{array}$ \\
\hline 6. & Respondent 6 & "Maintenance is still maintained because staff keep coming to work" \\
\hline 7. & Respondent 7 & $\begin{array}{l}\text { "Maintaining facilities and infrastructure according to government regulations and also } \\
\text { implementing the COVID-19 health protocol" } \\
\text { "Scheduled maintenance according to conditions at normal times" }\end{array}$ \\
\hline 8. & Respondent 8 & "Walking as usual" \\
\hline 9. & Respondent 9 & $\begin{array}{l}\text { "Maintenance by performing routine maintenance of tools and bringing in technicians to repair } \\
\text { troublesome tools" }\end{array}$ \\
\hline 10. & Respondent 10 & \\
\hline
\end{tabular}

Source: Results of interviewees, 2021

Based on the results of the interview, it is known that all respondents stated that the maintenance of facilities and infrastructure during the COVID-19 pandemic continues to be carried out regularly. Maintenance continues as usual, responsive to damage by adjusting to government regulations and implementing the COVID-19 health protocol.

\subsubsection{Process evaluation}

The evaluation process is aimed at ensuring that the program is developed by regulations, and has proceeded according to plan. The results of the interview in terms of the process are as follows.

\subsubsection{Programs Conducted to Implement Management Functions}

The results of interviews about the program carried out to implement the management function of the resource persons can be seen in the following table:

Table 11. Interview Results of Respondents Process Aspects About Programs Conducted to Implement Management Functions

\begin{tabular}{|c|c|c|}
\hline No & Source person & Interview result \\
\hline 1. & Respondent 1 & "Sharing work schedule" \\
\hline 2. & Respondent 2 & $\begin{array}{l}\text { "Program for Making Insulation/Acrylic at several work desks at HSC, GPLA, so that services to } \\
\text { stakeholders and staff/staff are safer, calmer, and better" }\end{array}$ \\
\hline 3. & Respondent 3 & $\begin{array}{l}\text { "Monitoring, analyzing, evaluating and implementing following the conditions of the COVID-19 } \\
\text { pandemic" }\end{array}$ \\
\hline 4. & Respondent 4 & "Training some additional supporting skills" \\
\hline 5. & Respondent 5 & $\begin{array}{l}\text { "Mental strengthening of employees to stay alert, that through the pool we can build heaven in each } \\
\text { other's families" }\end{array}$ \\
\hline 6. & Respondent 6 & "Reducing hours of use, reducing working hours" \\
\hline 7. & Respondent 7 & $\begin{array}{l}\text { "There is no special program in implementing our management functions under government } \\
\text { regulations and the COVID-19 health protocol" }\end{array}$ \\
\hline 8. & Respondent 8 & "Collaboration and controlling" \\
\hline 9. & Respondent 9 & "Process implementation program" \\
\hline 10. & Respondent 10 & $\begin{array}{l}\text { "The new order program is to maximize all management functions to increase fitness income during } \\
\text { the pandemic, facilities, human resources, and services by the health protocols" }\end{array}$ \\
\hline
\end{tabular}

Source: Results of interviewees, 2021

Based on the results of the interview, it is known that most of the respondents stated that the program carried out to implement the management function during the COVID-19 pandemic was a program that led to a new order with implement programs according to government regulations and the COVID-
19 health protocol. There are no special programs but only adjustments such as setting working hours and monitoring, analyzing, evaluating, and implementing programs following the conditions of the COVID-19 pandemic. 


\subsubsection{Program Socialization Process}

The results of interviews about the program socialization process towards the source person can be seen in the following table:

Table 12. Interview Results of Respondents Process Aspects About the Program Socialization Process

\begin{tabular}{|c|l|l|}
\hline No & Source person & \\
\hline 1. & Respondent 1 & "By conducting regular monthly internal meetings" \\
\hline 2. & Respondent 2 & $\begin{array}{l}\text { "Usually the initial information is disseminated from the Center (Ministry, then forwarded through } \\
\text { the University, Faculty, to the smallest unit to the implementing staff, or stakeholders (lecturers, } \\
\text { educators, students, customers/users from outside)" }\end{array}$ \\
\hline 3. & Respondent 3 & "Through print media, collaboration with agencies or clubs, or personal" \\
\hline 4. & Respondent 4 & "It's been going well and enthusiastic" \\
\hline 5. & Respondent 5 & $\begin{array}{l}\text { "Through the notice board in front of the pond, so that the public can know. Some customers who } \\
\text { have WhatsApp numbers, we call them to convey them to their colleagues" }\end{array}$ \\
\hline 6. & Respondent 6 & $\begin{array}{l}\text { "From management, we convey to users to be able to look after each other and obey the rules during } \\
\text { the pandemic and it is recommended not to gather together first" }\end{array}$ \\
\hline 7. & Respondent 7 & $\begin{array}{l}\text { "Usually socialization is through social media, WhatsApp and also sticks to the rules on fitness (can } \\
\text { be through direct announcements and also make correct / bulletin boards) regarding the programs } \\
\text { implemented" }\end{array}$ \\
\hline 8. & Respondent 8 & "Through social media" \\
\hline 9. & Respondent 9 & "Through social media" \\
\hline 10. & Respondent 10 & "Socialization by involving existing stakeholders" \\
\hline
\end{tabular}

Source: Results of interviewees, 2021

Based on the results of the interview, it can be seen that most of the respondents stated that the program socialization process during the COVID-19 pandemic was carried out through social media. In addition, it is also done through print media and bulletin boards.

\subsubsection{Time Management}

The results of interviews about time management during the COVID-19 pandemic with resource persons can be seen in the following table:

Table 13. Interview Results of Respondents Process Aspects About Time Management

\begin{tabular}{|c|l|l|}
\hline No & Source person & \\
\hline 1. & Respondent 1 & "Adjusting policies from the leadership and applicable rules" \\
\hline 2. & Respondent 2 & $\begin{array}{l}\text { "By making a Service Work Schedule in each Sub. Coordinators who are known to the leadership and } \\
\text { stakeholders" }\end{array}$ \\
\hline 3. & Respondent 3 & $\begin{array}{l}\text { "Adjusting to central or university regulations and there are still limitations on time and the number of } \\
\text { people involved" }\end{array}$ \\
\hline 4. & Respondent 4 & "Stay well-conditioned" \\
\hline 5. & Respondent 5 & "Yes, employees can have a break from 12.00-13.00, so that the task can be fresher" \\
\hline 6. & Respondent 6 & $\begin{array}{l}\text { "For clear time management, it will decrease, because it also refers to government regulations that have } \\
\text { been set" }\end{array}$ \\
\hline 7. & Respondent 7 & "Management time according to government and leadership recommendations" \\
\hline 8. & Respondent 8 & "Made shift guard officer" \\
\hline 9. & Respondent 9 & "Normal movement as usual" \\
\hline 10. & Respondent 10 & $\begin{array}{l}\text { "Time management is adjusted to the circular from the government regarding activities and times } \\
\text { during the pandemic" }\end{array}$ \\
\hline
\end{tabular}

Source: Results of interviewees, 2021

Based on the results of the interview, it can be concluded that the respondents stated that the time management during the COVID-19 pandemic had adjustments. The adjustments made are related to the limitation of service time during the pandemic and also the rules regarding health protocols that must be carried out. Management of service time is adjusted to government regulations and leadership.

\subsubsection{Process Supervision By Manager}

The results of interviews about the supervisory process by managers against resource persons can be seen in the following table: 
Table 14. Interview Results of Respondents Process Aspects About the Supervisory Process by Managers

\begin{tabular}{|c|l|l|}
\hline No & \multicolumn{1}{|c|}{ Source person } & \multicolumn{1}{c|}{ Interview result } \\
\hline 1. & Respondent 1 & "Through field observations, discussions and data observations" \\
\hline 2. & Respondent 2 & $\begin{array}{l}\text { "Monitoring, direct viewing/via WA/WAG communication for routine work, incidental/urgent work, } \\
\text { also routinely monitoring staff work in the field" }\end{array}$ \\
\hline 3. & Respondent 3 & "With the division of tasks in rotation or picket" \\
\hline 4. & Respondent 4 & "All the time the manager monitors" \\
\hline 5. & Respondent 5 & "Because the manager meets every day, you can see directly at their stay location" \\
\hline 6. & Respondent 6 & "Always entrust the process to users or their staff and provide tools for process needs" \\
\hline 7. & Respondent 7 & $\begin{array}{l}\text { "We carry out supervision at all times in the field (fitness center) especially in the afternoon because } \\
\text { in the afternoon there are quite a lot of fitness members, if there are obstacles, we will immediately } \\
\text { execute them together" }\end{array}$ \\
\hline 8. & Respondent 8 & "Always conduct periodic monitoring evaluation" \\
\hline 9. & Respondent 9 & "Process related monitoring" \\
\hline 10. & Respondent 10 & $\begin{array}{l}\text { "Supervision is carried out by the manager on all matters relating to service and equipment } \\
\text { maintenance" }\end{array}$ \\
\hline
\end{tabular}

Source: Results of interviewees, 2021

Based on the results of the interview, it can be seen that the respondents stated that the supervisory process by managers during the COVID-19 pandemic was carried out directly in the field. Managers carry out direct supervision by monitoring the work of staff in the field. Supervision by the manager is carried out routinely, even most managers carry out supervision every day.

\subsubsection{Difficulties in Implementing Management Functions}

The results of interviews about the difficulties in implementing the management function of the resource persons can be seen in the following table:

Table 15. Interview Results of Respondents Process Aspects About Difficulties in Implementing Management Functions

\begin{tabular}{|c|l|l|}
\hline No & \multicolumn{1}{|c|}{ Source person } & \multicolumn{1}{c|}{ Interview result } \\
\hline 1. & Respondent 1 & $\begin{array}{l}\text { "The difficulty is when it requires a large amount of energy because it is divided into scheduling, } \\
\text { of course, you have to wait for the right time" }\end{array}$ \\
\hline 2. & Respondent 2 & $\begin{array}{l}\text { "Difficulty arises because with the staff work schedule arrangement, for work on } \\
\text { maintenance/repair of infrastructure facilities in the field that cannot be done online/online and } \\
\text { must be offline, with the number of personnel available/ready at the office sometimes the } \\
\text { completion of work becomes a bit hampered" }\end{array}$ \\
\hline 3. & Respondent 3 & "Lack of understanding of the process for users from the general public" \\
\hline 4. & Respondent 4 & $\begin{array}{l}\text { "The difficulty is because it is limited by the situation where no crowds are allowed and remain a } \\
\text { protocol" }\end{array}$ \\
\hline 5. & Respondent 5 & "There is not any" \\
\hline 6. & Respondent 6 & $\begin{array}{l}\text { "There is. Because during the pandemic the income is reduced. And for the funding system or } \\
\text { pending facility submissions" }\end{array}$ \\
\hline 7. & Respondent 7 & "Difficulty in supervising fitness members because they come from different personalities" \\
\hline 8. & Respondent 8 & "Delays in delivering information to members and members due to problems with wifi signal" \\
\hline 9. & Respondent 9 & "No trouble" \\
\hline 10. & Respondent 10 & "The difficulty is educating every visitor to obey the health protocols" \\
\hline
\end{tabular}

Source: Results of interviewees, 2021

Based on the results of interviews about the difficulties in implementing the management function, it can be concluded that most of the respondents stated that there were difficulties. These difficulties include difficulties in distributing staff work schedules, difficulties in completing work that cannot be done online, delays in delivering information, difficulties in educating about health protocols, and difficulties related to funding.

\subsubsection{Manager's Evaluation Process}

The results of interviews about the evaluation process carried out by managers on resource persons can be seen in the following table: 
Table 16. Interview Results of Respondents Process Aspects About the Evaluation Process Conducted by Managers

\begin{tabular}{|c|l|l|}
\hline No & \multicolumn{1}{|c|}{ Source person } & \multicolumn{1}{c|}{ Interview result } \\
\hline 1. & Respondent 1 & "Through monthly evaluation, through direct discussion" \\
\hline 2. & Respondent 2 & $\begin{array}{l}\text { "By giving warnings, input, suggestions, guidance to staff to be more optimal in completing the } \\
\text { work that is their responsibility" }\end{array}$ \\
\hline 3. & Respondent 3 & "Through meetings or meetings with all staff every time there will be activities or after activities" \\
\hline 4. & Respondent 4 & "Monthly evaluation" \\
\hline 5. & Respondent 5 & $\begin{array}{l}\text { "There is no shortage of employees, meaning that they work according to schedule. However, the } \\
\text { few visitors become a big field of worship. This is what I often tell them so that we share the } \\
\text { same fate" }\end{array}$ \\
\hline 6. & Respondent 6 & $\begin{array}{l}\text { "Conducting discussions or evaluations within management or asking for direction from the } \\
\text { leadership." }\end{array}$ \\
\hline 7. & Respondent 7 & $\begin{array}{l}\text { "We usually do the evaluation process every month (through joint meetings) but if there is an } \\
\text { incident at that time, if it is not by the implementation of the management function that we have } \\
\text { agreed upon, we will immediately act on it" }\end{array}$ \\
\hline 8. & Respondent 8 & "It is done blended (offline and online)" \\
\hline 9. & Respondent 9 & "Performance evaluation and process implementation through direct observation" \\
\hline 10. & Respondent 10 & "Internal and external evaluation" \\
\hline
\end{tabular}

Source: Results of interviewees, 2021

Based on the results of interviews about the evaluation process carried out by managers during the COVID-19 pandemic, it can be seen that most of the respondents stated that the evaluation was still being carried out. Evaluations carried out by managers include discussions or also through meetings. Some evaluations are carried out in person, some are through online meetings to adjust to the COVID-19 pandemic situation.

\subsubsection{Product Evaluation}

Product evaluation is an evaluation at the end of the program regarding the output or product that can provide a complete picture of the various achievements of the program. The results of interviews on the product aspect of the sports facility management function are as follows.

\subsubsection{Sports Facility Management Service Quality}

The results of interviews about the quality of sports facilities management services to resource persons can be seen in the following table:

Table 17. Interview Results of Product Aspect Respondents About Service Quality Management of Sports Facilities

\begin{tabular}{|c|c|c|}
\hline No & Source person & Interview result \\
\hline 1. & Respondent 1 & "Trying to stay following the standards that have been determined, we optimize it as best we can" \\
\hline 2. & Respondent 2 & $\begin{array}{l}\text { "Ensuring that the quality of service to customers/users remains good, immediately responds to } \\
\text { any requests/inputs from OR infrastructure managers or outside customers" }\end{array}$ \\
\hline 3. & Respondent 3 & "As much as possible to provide the best service" \\
\hline 4. & Respondent 4 & "Good stay" \\
\hline 5. & Respondent 5 & $\begin{array}{l}\text { "We are still checking the temperature of visitors. Record your name and WA number so you can } \\
\text { track it if needed. We constantly urge you to go to the pool so you can have friends so you can } \\
\text { watch over each other." }\end{array}$ \\
\hline 6. & Respondent 6 & "Services are still the same as usual even though field users have decreased" \\
\hline 7. & Respondent 7 & $\begin{array}{l}\text { "The quality is getting better (more assertive) because we are forced to implement health } \\
\text { protocols and government regulations during the COVID-19 pandemic" }\end{array}$ \\
\hline 8. & Respondent 8 & "Stay good and maximum to the members" \\
\hline 9. & Respondent 9 & "Well" \\
\hline 10. & Respondent 10 & $\begin{array}{l}\text { "The quality of service is further improved to provide a sense of security and satisfaction to } \\
\text { members and prospective members" }\end{array}$ \\
\hline
\end{tabular}

Source: Results of interviewees, 2021

Based on the results of interviews about the quality of sports facility management services during the covid 19 pandemic, it can be seen that respondents stated that the quality of sports facilities services remained good. Services are still provided under existing service standards and are optimized in their services. 


\subsubsection{Staff Performance During the COVID-19 Pandemic}

The results of interviews about staff performance during the COVID-19 pandemic with resource persons can be seen in the following table:

Table 18. Interview Results of Product Aspect Respondents About Staff Performance During the Covid 19 Pandemic

\begin{tabular}{|c|l|l|}
\hline No & \multicolumn{1}{|c|}{ Source person } & \multicolumn{1}{|c|}{ Interview result } \\
\hline 1. & Respondent 1 & "Keep up to the task" \\
\hline 2. & Respondent 2 & $\begin{array}{l}\text { "Sub. The UKBMN coordinator is still good according to the work schedule, sometimes staff } \\
\text { friends still want to work/enter the office even though it is on the WFH scheduled work } \\
\text { schedule" }\end{array}$ \\
\hline 3. & Respondent 3 & "Overall going well" \\
\hline 4. & Respondent 4 & "Stay positive" \\
\hline 5. & Respondent 5 & $\begin{array}{l}\text { "Performance according to the stated schedule and enthusiasm from arriving at preparing to go } \\
\text { home" }\end{array}$ \\
\hline 6. & Respondent 6 & "For staff performance, while still normal as usual" \\
\hline 7. & Respondent 7 & $\begin{array}{l}\text { "Performance is the same as usual when there is no COVISD-19, it's just that the } \\
\text { implementation of health protocols is prioritized, for example after finishing using fitness } \\
\text { equipment or when employees are closed by spraying disinfectant (sterilizing tools), we also } \\
\text { limit hours and the number of fitness members in using employee performance tools to become } \\
\text { add extra by implementing health protocols and regulations from the government" }\end{array}$ \\
\hline 8. & Respondent 8 & "Stay awake and committed" \\
\hline 9. & Respondent 9 & "Well" \\
\hline 10. & Respondent 10 & "The performance of the staff according to their respective duties has been going well" \\
\hline
\end{tabular}

Source: Results of interviewees, 2021

In the results of interviews regarding staff performance during the COVID-19 pandemic, it was found that respondents stated that the staff's performance during the COVID-19 pandemic continued to run well. The staff continues to work according to the main task and remains enthusiastic. There are adjustments to staff work related to schedules and implementation of health protocols and government regulations.

\subsubsection{Income During the COVID-19 Pandemic On Target}

The results of interviews about income during the COVID-19 pandemic according to the target of the interviewees can be seen in the following table:

Table 19. Interview Results of Product Aspect Respondents About Income During the Covid 19 Pandemic On Target

\begin{tabular}{|c|l|l|}
\hline No & Source person & \multicolumn{1}{c|}{ Interview result } \\
\hline 1. & Respondent 1 & "With the lowered target, the target so far has been achieved" \\
\hline 2. & Respondent 2 & "Sorry because we don't manage directly, so we don't know whether it's on target or not" \\
\hline 3. & Respondent 3 & "Around the target sometimes there is a period of ups and downs for each month" \\
\hline 4. & Respondent 4 & "Appropriate but lowered target" \\
\hline 5. & Respondent 5 & "Revenue is only 30\%" \\
\hline 6. & Respondent 6 & "No. For income, during the pandemic, there is a temporary decline" \\
\hline 7. & Respondent 7 & $\begin{array}{l}\text { "It is not yet on target and tends to decrease because we are also implementing health protocols } \\
\text { by government recommendations and COVID-19 health protocols, including activity } \\
\text { restrictions" }\end{array}$ \\
\hline 8. & Respondent 8 & "In accordance" \\
\hline 9. & Respondent 9 & "Slightly downhill" \\
\hline 10. & Respondent 10 & "Not on target due to the implementation of lockdown, PPKM, and others" \\
\hline
\end{tabular}

Source: Results of interviewees, 2021

The results of interviews about income during the COVID-19 pandemic whether it was on target, some respondents stated that income was on target with the lowered target. Some respondents stated that they had not met the target due to the implementation of the lockdown, PPKM, and others.

\subsubsection{If Target Income, Awards Given To Employees}

The results of interviews about the awards given to employees to resource persons can be seen in the following table: 
Table 20. Interview Results of Product Aspect Respondents About Awards Given to Employees

\begin{tabular}{|c|l|l|}
\hline No & Source person & \multicolumn{1}{|c|}{ Interview result } \\
\hline 1. & Respondent 1 & "There will be a reward" \\
\hline 2. & Respondent 2 & $\begin{array}{l}\text { "Sorry because we don't manage directly, so don't know if there is an award } \\
\text { or not." }\end{array}$ \\
\hline 3. & Respondent 3 & "There are rewards both financially and morally" \\
\hline 4. & Respondent 4 & "There are no awards yet" \\
\hline 5. & Respondent 5 & "So far, awards are only with value rewards" \\
\hline 6. & Respondent 6 & $\begin{array}{l}\text { "Giving sincere compliments, celebrating successes achieved, giving } \\
\text { memorable awards and giving bonuses" }\end{array}$ \\
\hline 7. & Respondent 7 & $\begin{array}{l}\text { "We usually give awards in the form of material bonuses (usually in the } \\
\text { form of money)" }\end{array}$ \\
\hline 8. & Respondent 8 & "Providing holiday and year-end allowances" \\
\hline 9. & Respondent 9 & "Giving rewards" \\
\hline 10. & Respondent 10 & "Rewards" \\
\hline
\end{tabular}

Source: Results of interviewees, 2021

The results of interviews about the awards given to employees if the income is according to the target, results show that most of the respondents stated that they gave rewards to employees. Rewards given to employees are in the form of material, namely money and moral awards.
3.1.4.5. If the income is not targeted, the solution to the problem

The results of interviews about solutions to problems if income does not match the target of the informants can be seen in the following table:

Table 21. Interview Results of Product Aspect Respondents About the Evaluation Process Conducted by Managers

\begin{tabular}{|c|c|c|}
\hline No & Source person & Interview result \\
\hline 1. & Respondent 1 & "Preparing attractive programs to attract clients" \\
\hline 2. & Respondent 2 & $\begin{array}{l}\text { "The target in } 1 \text { year can be monitored/monitored from the income recap at the end of each } \\
\text { month, usually by the leadership/dean, the income achievement of each unit will always be } \\
\text { monitored, and then a unit manager coordination meeting is held with evidence/recap of income } \\
\text { from the finance department. Then from the Coordination Meeting, the Leader asked the } \\
\text { Manager/unit to further boost its income so that at the end of the year the income } \\
\text { target/achievement is achieved. So the leader is doing good control" }\end{array}$ \\
\hline 3. & Respondent 3 & $\begin{array}{l}\text { "Increasing publications, rent waivers, and excellent service to users so that they are happy and } \\
\text { satisfied for further use as well as promotional media" }\end{array}$ \\
\hline 4. & Respondent 4 & "Seeing the problem, if you have to close, it's certainly difficult" \\
\hline 5. & Respondent 5 & "Yes, just be patient because of the nature of the phenomenon that is not forever" \\
\hline 6. & Respondent 6 & "Creating a new strategy when the original marketing strategy failed" \\
\hline 7. & Respondent 7 & $\begin{array}{l}\text { "Usually we conduct a thorough evaluation (evaluation once a month through joint meetings) } \\
\text { where the company's shortcomings lie, and we look for solutions together" }\end{array}$ \\
\hline 8. & Respondent 8 & "Intensifying the socialization of tennis court facilities through social media" \\
\hline 9. & Respondent 9 & $\begin{array}{l}\text { "This is natural because there are indeed many limitations so that user access is not as free as } \\
\text { before" }\end{array}$ \\
\hline 10. & Respondent 10 & "By imposing a new order" \\
\hline
\end{tabular}

Source: Results of interviewees, 2021

The results of the interview about the solution to the problem if the income is not according to the target showed that most of the respondents stated that the steps taken were evaluating the program, preparing programs and strategies that could attract clients, then promotion and publication.

\subsection{Discussion}

Context evaluation relates to the specification of the program environment, unmet needs, the character of the evaluation subject and the program objectives to be achieved (Widoyoko, 2017). Evaluation of the context aspect of the management function includes the management of facilities management, implementation of management functions, objectives of implementing management functions, facility management planning, and long-term facility 
management plans. Planning can be defined as the process of setting goals through appropriate and systematic means or methods to achieve goals. (Harsono, 2010). Planning can be defined as the process of setting goals through appropriate and systematic means or methods to achieve goals. Planning includes decision-making activities because it includes the selection of decision alternatives (Terry, 2003). Heri (2016) says planning includes selecting or setting organizational goals and determining strategies, policies, projects, programs, procedures, methods, systems, budgets, and standards needed to achieve goals. The majority of respondents stated that the management of sports facilities was carried out following health protocols issued by the central, provincial, and Yogyakarta State University. The implementation of management functions is constrained by limited personnel, as well as restrictions on service hours. The purpose of implementing the management function is to service functions and cooperation with stakeholders continue to run well. Facility management planning is adjusted to health protocols and government regulations during the COVID-19 pandemic. Apart from keeping existing sports facilities to be maintained/maintained continuously, long-term plans are made to develop efficient programs by adjusting to the new order after the COVID-19 pandemic.

Input evaluation is useful when the allocation of resources (eg staff, budget, time) is part of planning a program or writing a proposal. Incorporating an Input evaluation approach into program development helps to maintain maximum response to ongoing program needs (context) (Frye \& Hemmer, 2012). The evaluation of the management of sports facilities in the input aspect includes the implementation of organizing functions during the pandemic, staff working according to their duties, management efforts to improve service quality, the interest of members during the pandemic, maintenance of facilities and infrastructure. An organization is a group of people who interact and work together to realize a common goal (Siswanto, 2005). Every organization must have a proper organizational structure. The organizational structure is reflected in the form of a chart or graphic called an organizational chart. (Handoko, 2000). Susanto (2002) says that the most important organizational asset and must be considered by management is human (human resources). The steps taken are by organizing human resources in jobs that are under their skills, making work schedules, and maintaining good service to users, and carrying out facility management by health protocols and government regulations. All staff work according to their duties and functions during the COVID-19 pandemic. Efforts made to improve the quality of services during the pandemic include maintaining sports facilities, responding quickly to repairs if there are infrastructures that need to be repaired, providing services following the standard of service needs while still emphasizing the covid 19 process. The interest of members/users of sports facilities during the COVID19 pandemic has decreased. Maintenance continues as usual, responsive to damage by adjusting to government regulations and implementing the covid 19 health protocol.

Process evaluation is designed to provide information throughout program implementation and support program managers in ensuring that programs are developed under regulations, run according to plan, and are complemented by structural decisions (Duman \& Akbas, 2017). Evaluation in terms of the process of the management function of sports facilities includes programs carried out to implement management functions, program socialization processes, time management, supervisory processes by managers, difficulties in implementing management functions and evaluation processes carried out by managers.) do what should be done and motivate it to achieve organizational goals, some regulate, direct, motivate, provide sanctions and others. Amir (2006). Supervision is a process to implement what work has been carried out, evaluate it, and if necessary correct it with the intention that the implementation of the work is by the original plan (Manullang, 2005). Programs that lead to a new order with implement the program according to government regulations and the COVID-19 health protocol. The program socialization process during the COVID-19 pandemic is carried out through social media, print, electronic. Management service times are adjusted to government regulations and the overnight leadership of the Pandemic. Managers carry out direct supervision by monitoring the work of staff in the field. These difficulties include difficulties in distributing staff work schedules, difficulties in completing work that cannot be done online, delays in delivering information, difficulties in educating about health protocols, and difficulties related to funding. Some evaluations are carried out in person, some are through online meetings to adjust to the COVID-19 pandemic situation.

In the product evaluation stage, information is collected at the end of the program regarding the output or product, and the product obtained is compared with expectations (Duman \& Akbas, 2017). Product evaluation in this study focuses on the quality of sports facility management services, staff performance, revenue targets during the COVID-19 pandemic, and awards are given to employees. Services are still provided by existing service standards and are optimized in their services. There is an adjustment to the work of the staff related to schedules and implementation of health protocols and government regulations. Some respondents stated that their income was in line with the target that was lowered. Some respondents stated that they had not met the target because of the implementation of lockdown, PPKM, and others. Rewards given to 
employees are in the form of material, namely money and moral awards. The solution to the problem is the use of advice and infrastructure effectively and efficiently, evaluating programs, preparing programs and strategies that can attract clients, then promoting and publishing as well as creating an Android-based integrated service system. The purpose of the promotion is to attract consumers to join or use sports facilities(Yuniana \& Nasrulloh, 2019). In addition, it is also necessary to use the facilities and infrastructure of sports facilities effectively and efficiently. (Kristi, 2014). So that the promotion is carried out intensively and the use of sports facilities that are effective and efficient through social media, print media, and electronic media are expected to be able to provide increased income.

\section{CONCLUSION}

The implementation of management functions is constrained by limited personnel, as well as restrictions on service hours. These difficulties include difficulties in distributing staff work schedules, difficulties in completing work that cannot be done online, delays in delivering information, difficulties in educating about health protocols, and difficulties

\section{REFERENCES}

Amir. (2006). Pengantar Ilmu Komunikasi. Medan. Pustaka Bangsa.

Arthur, L., \& Cox, E. (2014). From evaluation to research. International Journal of Research \& Method in Education, 37(2), PP: 137-150. DOI: $10.1080 / 1743727$ X.2013.795529

Duman, S. N., \& Akbaş, O. (2017). Evaluation of Turkish and mathematics curricula according to value-based evaluation model. Cogent Education, 4(1291174), PP: 1-10. DOI: 10.1080/2331186X.2017.1291174

Eksteen, E. (2014). Sport Management. Eksteen \& bookboon.com : ISBN 978-87-403-0644-6.

Frye, A. W., \& Hemmer, P. A. (2012). Program evaluation models and related theories: AMEE Guide No. 67. Medical Teacher, 34(5), PP: 288-299. DOI: $10.3109 / 0142159 X .2012 .668637$

Guyadeen, D., \& Seasons, M. (2016). Evaluation Theory and Practice: Comparing Program Evaluation and Evaluation in Planning: Https://Doi.Org/10.1177/0739456X16675930, $38(1)$, 98-110. https://doi.org/10.1177/0739456X16675930

Hakan, K., \& Seval, F. (2011). CIPP evaluation model scale: Development, reliability, and validity. Procedia Social and Behavioral Sciences, 15 (2011) PP: 592-599. DOI: 10.1016/j.sbspro.2011.03.146

Handoko, T. Hani. (2000). ManajemenEdisi 2. Yogyakarta: BPFE related to funding. The steps taken are by organizing human resources in jobs that are following their skills, making work schedules, and maintaining good service to users, and carrying out facility management by health protocols and government regulations. The interest of members/users of sports facilities during the COVID-19 pandemic has decreased. Efforts made to improve the quality of services during the pandemic include maintaining sports facilities, responding quickly to repairs if there are infrastructures that need to be repaired, providing services following the standard of service needs while still emphasizing the covid 19 process. Some respondents stated that they had not met the target because of the implementation of lockdown, PPKM, and others. The solution to the problem is the use of sports facilities and infrastructure effectively and efficiently, evaluating programs, preparing programs and strategies that can attract clients, then promoting and publishing, as well as creating an Android-based integrated service system. So that with the effective and efficient use of sports facilities and promotions carried out intensively through social media, print media, and electronic media, it is expected to be able to provide increased income.

Harsono. (2010). Manajemen Pengantar Sekolah Tinggi Ilmu Ekonomi YKPN. Yogyakarta.

Heri. (2016). Manajemen Pengelolaan Fasilitas Olahraga Milik Pemerintah Kabupaten Jepara. Semarang: UNNES.

Hunter, D. E. K., \& Nielsen, S. B. (2013). Performance management and evaluation: Exploring complementarities. In S. B. Nielsen \& D. E. K. Hunter (Eds.), Performance management and evaluation. New Directions for Evaluation, 137, PP: 7-17. DOI: 10.1002/ev.20042

Kristi, P.D., dan Nasrulloh, A. (2014). Efektivitas pemanfaatan sarana dan prasaranalatihan beban di fitness center GOR. MEDIKORA, $O(1) . \quad$ https://journal.uny.ac.id/index.php/ medikora/article/view/4579

Manullang, M. 2005. Dasar-Dasar Manajemen. Yogyakarta : UGM University Press.

Nasrulloh, A., Sumaryanto, ., Sumarjo, ., \& Nugroho, S. (2020). The Analysis of Management Function of Sport Hall (GOR) Yogyakarta State University. https://doi.org/10.5220/0009785202960302

Nasrulloh, A., Sumaryanto, M., Nugroho, S., \& Sumarjo, M. (2019). Strategy of Sport Industry Development as Supporting Tourism in DIY. May 2020. https://doi.org/10.2991/yishpesscois-18.2018.62

Nasrulloh, A., Sumaryanto, Sumarjo, Nugroho, S., \& Antoni, M. S. (2021). Does the Implementation of the Management Function Have an Impact on Service Quality? A Study at the HSC Fitness Center. International Journal of Human 
Movement and Sports Sciences, 9(5), 10191028.

https://doi.org/10.13189/SAJ.2021.090524

Nkwake, A. M. (2015). Credibility, validity, and assumptions in program evaluation methodology. New York: Springer.

Siswanto. (2005). PengantarManajemen. Jakarta: Bumi Aksara.

Stufflebeam, D.L., Coryn, Chris L.S.. (2014). Evaluation: Theory, Models, \& Application (Second Edition). San Fransisco: Jossey-Bass.

Susanto. (2002). Dasar-dasarManajemen. Jakarta: CV. Miswa.
Terry, George.R. 2003. Prinsip-prinsip Manajemen. Terjemahan J. Smith D.F.M. Jakarta: Bumi Aksara.

Wawan, Suherman, S. (2002). Manajemen Olahraga. Yogyakarta: Fakultas Ilmu Keolahragaan UNY.

Widoyoko, S. E. P. (2017). Evaluasi program pelatihan. Yogyakarta: Pustaka Pelajar.

Yuniana, R., \& Nasrulloh, A. (2019). Tingkat kepuasan members terhadap strategi pemasaran di lembah fitness centre Universitas Gajah Mada. MEDIKORA, 18(1). https://doi.org/10.21831/medikora.v18i1.29195 